\title{
Delineation of maize growing areas vis-à-vis climate and technology using statistical and geospatial techniques in Punjab
}

\author{
GURPREET KAUR ${ }^{1}$, SOM PAL SINGH ${ }^{1 *}$, R.K. SETIA ${ }^{2}$ and P.K. KINGRA ${ }^{1}$ \\ ${ }^{1}$ Department of Climate Change and Agricultural Meteorology, Punjab Agricultural University, Ludhiana-141 004, Punjab; \\ ${ }^{2}$ Punjab Remote Sensing Centre, Ludhiana - 141 004, Punjab \\ "Corresponding author:sompal69@pau.edu
}

\begin{abstract}
In the present investigation, maize growing areas in Punjab were delineated with respect to climate and technology variables using statistical and geospatial techniques. The effect of the climate (maximum temperature, minimum temperature and rainfall) and technology variables (fertilizers, irrigation) on maize yield was studied in spatio-temporal domain in maize growing areas of Punjab. Long-term data on climate and technology variables as well as maize productivity was collected for maize growing districts of the state. The maximum temperature during maize growing season was highest $\left(35.7^{\circ} \mathrm{C}\right)$ in Amritsar, the minimum temperature was highest $\left(25.3^{\circ} \mathrm{C}\right)$ in Ludhiana, whereas rainfall was highest (765.4 mm) in Gurdaspur. The results of Mann-Kendall test showed significant increase in maximum temperature @ $0.03^{\circ} \mathrm{C}_{\text {year }}{ }^{-1}$ in Hoshiarpur, Kapurthala, Patiala and Roopnagar and minimum temperature $@ 0.04^{\circ} \mathrm{C}$ year ${ }^{-1}$ in Gurdaspur, Hoshiarpur, Kapurthala and Roopnagar, @ $0.03^{\circ} \mathrm{C}$ year ${ }^{-1}$ in Jalandhar and @ $0.05^{\circ} \mathrm{C}$ year ${ }^{-1}$ in Ludhiana and Patiala districts. Analysis indicated that the maize yield was significantly higher in Ludhiana than other districts. Spatial variability in maize yield, climate and technology was studied using Geographic Information System (GIS). The integration of the layers of climate parameters with yield in GIS demarcated four major maize growing zones in Punjab.
\end{abstract}

Key words : Climate variability, technology, maize yield, GIS

Maize is one of the most important cereal crops after wheat and rice. It is used both as a food and feed crop as well as it is used as an industrial raw material such as alcoholic beverages, pharmaceuticals, gums, textiles, oil, proteins, food sweeteners and in paper and packaging industries etc (Kumar et al., 2018). Maize has highest genetic potential which allows it to grow in tropical, sub-tropical and temperate climates (Rathod et al., 2017). In order to feed the increasing world's population it is important that the production of three important cereal crops (rice, wheat and maize) be increased by $70 \%$ by 2050 . But due to climate change agricultural production is likely to be adversely affected, which may hinder the capability of many areas to attain the required goals for future food security (Lobell et al., 2008). In India area under maize crop is 9.63 million hectares with a production of 25.89 million tonnes and yield of 10.76 $\mathrm{q}$ acre $^{-1}$ in the year 2016-17. Punjab occupied an area of about 114 thousand hectares, with a production of 423 thousand tonnes and average yield was $15.01 \mathrm{q} \mathrm{acre}^{-1}$ during the year 2017-18 (Anonymous, 2019).

Depending on the locations, the increased temperature due to increased $\mathrm{CO}_{2}$ will have a great impact on food grain production. In tropical and sub-tropical countries like India, temperature is likely to rise by $1.0-2.0^{\circ} \mathrm{C}$ which may decrease the food production up to $30 \%$ (IPCC, 2014 and Johkan et al., 2011). Warming temperature reduces the crop growth periodby increasing phenological development and thus decreases the period of photosynthesis and biomass accumulation (Xiao et al., 2013 and 2015). Warming along with drought reduces greater yield due to the impact of higher vapour pressure deficit (VPD) on yield (Lobell et al., 2014). Maize growth and yield also reduces due to the decrease in precipitation and solar radiation (Mo et al., 2009; Liu et al., 2010; Tao and Zhang, 2011).

The state of Punjab is also suffering from the climatic variation during the last many decades. Geospatial technology offers many advantages over the traditional methods to collect, manipulate, evaluate and retrieve abundant spatially referenced data collected from different sources (Aronoff, 1991). In view of above the present study was conducted to show how the productivity of maize varies among different districts of Punjab and to see how the changing climate and technology variables affect the maize productivity. 


\section{MATERIALS AND METHODS}

\section{Data Collection}

Long term data (1971-2017) on maize productivity, fertilizer application and irrigation were collected from statistical abstracts of Punjab. Long term(1971-2017) climate data (maximum, minimum temperature and rainfall) during the maize growing season (June to September) was collected from Department of Climate Change and Agricultural Meteorology, Punjab Agricultural University (PAU) Ludhiana, different research stations of PAU, India Meterological Department and different websites.

\section{Statistical Analysis}

Long term weather and crop yield data were analyzed for the maize growing districts of Punjab viz., Gurdaspur, Hoshiarpur, Roopnagar, Amritsar, Jalandhar, Kapurthala, Ludhiana and Patiala by using statistical techniques like mean, standard deviation, coefficient of variation, MannKendall test and correlation.

\section{Spatial interpolation}

Spatial interpolation of maize yield and climate parameters (maximum, minimum temperature and rainfall) was done using Inverse Distance Weighted (IDW) method in ArcGIS 10.4 by taking the average from 1971 to 2017 . The characterization of the maize growing districts of Punjab was then done by overlaying the interpolated layers of maize yield, technology and climate parameters.

\section{RESULTS AND DISCUSSION}

\section{Spatial and temporal variations in maize yield}

The highest average maize yield was noticed in Ludhiana (2873.6 $\left.\pm 1286.9 \mathrm{~kg} \mathrm{ha}^{-1}\right)$ followed by Kapurthala $\left(2762.5 \pm 1274.8 \mathrm{~kg} \mathrm{ha}^{-1}\right)$ and lowest in Gurdaspur $\left(1828 \pm 647.1 \mathrm{~kg} \mathrm{ha}^{-1}\right)$. The coefficient of variation was highest in Patiala (53.7\%) which indicated high variability and less consistency in maize yield in this district followed by Kapurthala (46.1\%) and lowest in Gurdaspur (35.4\%) which showed high consistency and low variability in maize yield in this district. The rate of increase $\left(74.3 \mathrm{~kg} \mathrm{ha}^{-1}\right.$ year$\left.{ }^{1}\right)$ was highest for Patiala and the value of $\mathrm{R}^{2}$ was observed to be highest for Hoshiarpur (0.84) (Table 1). Spatial variability showed that maize yield at Gurdaspur remained between 1800-2000 $\mathrm{kg} \mathrm{ha}^{-1}$, at Roopnagar, it remained between 2000-2200 kg ha-1 , at Hoshiarpur and Patiala, it remained between $2200-2400 \mathrm{~kg} \mathrm{ha}^{-1}$, at Amritsar, it remained between $2400-2600 \mathrm{~kg} \mathrm{ha}^{-1}$, at Jalandhar and Kapurthala, it remained between $2600-2800 \mathrm{~kg} \mathrm{ha}^{-1}$ and at Ludhiana it remained between 2800-3000 $\mathrm{kg} \mathrm{ha}^{-1}$ (Fig. 1).

\section{Variations in climatic parameters during maize growing season}

The highest average maximum temperature during maize growing seasons $\left(35.7 \pm 0.9^{\circ} \mathrm{C}\right)$ was noticed in Amritsar, followed by Kapurthala $\left(35.2 \pm 1.3^{\circ} \mathrm{C}\right)$ and lowest in Gurdaspur $\left(33.3 \pm 1^{\circ} \mathrm{C}\right)$. However, the variability in maximum temperature was highest in Roopnagar (5.4\%) which indicated low consistency and high variability in maximum temperature in this district, followed by Hoshiarpur (3.7\%) and lowest in Ludhiana (2.1\%) which indicated high consistency and low variability in maximum temperature in this district. The rate of increase in maximum temperature was highest at Roopnagar $\left(0.08^{\circ} \mathrm{C}_{\text {year }}{ }^{-1}\right)$ and the value of $\mathrm{R}^{2}$ was observed to be highest for Roopnagar (0.39) (Table 2). The highest average minimum temperature during maize growing seasons $\left(25.3 \pm 1^{\circ} \mathrm{C}\right)$ was observed in Ludhiana, followed by Kapurthala $\left(24.6 \pm 1.1^{\circ} \mathrm{C}\right)$ and lowest in Gurdaspur $\left(23 \pm 1.5^{\circ} \mathrm{C}\right)$. The variability in minimum temperature was highest in Roopnagar $(7.3 \%)$ which indicated high variability and less consistency in minimum temperature in this district, followed by Gurdaspur (6.5\%) and lowest in Amritsar (3.3\%) which indicated low variability and high consistency in minimum temperature in this district. The rate of increase in minimum temperature was highest at Roopnagar $\left(0.09^{\circ} \mathrm{C}_{\text {year }}{ }^{-1}\right)$ and the value of $\mathrm{R}^{2}$ was observed to be highest for Ludhiana (0.70). Kingra et al. (2017) also reported significant climatic variations in different agroclimatic regions of Punjab.

The highest average rainfall during maize growing seasons was observed in Gurdaspur $(765.4 \pm 239.8 \mathrm{~mm})$, followed by Jalandhar $(760.5 \pm 544.7 \mathrm{~mm})$ and lowest in Amritsar $(549.3 \pm 193.1 \mathrm{~mm})$. The coefficient of variation was highest in Jalandhar (71.6\%) which indicated high variability and less consistency in rainfall in this district, followed by Patiala (41.1\%) and lowest in Roopnagar (31\%) which indicated low variability and high consistency in rainfall in this district. The rate of increase in rainfall was highest at Jalandhar $\left(15.58\right.$ mm year $\left.^{-1}\right)$ and the value of $\mathrm{R}^{2}$ was observed to be highest for Jalandhar (0.15). Similarly, Mann-Kendall test was performed to see the variability in maximum temperature. Gurdaspur showed significant increase in mean minimum temperature $@ 0.04^{\circ} \mathrm{C}_{\text {year }}{ }^{-1}$. Hoshiarpur showed significant increase in maximum and minimum temperature (a) 0.03 and $0.04^{\circ} \mathrm{C}_{\text {year }}{ }^{-1}$ respectively. Jalandhar showed significant increase in minimum temperature @ $0.03^{\circ} \mathrm{C}$ year ${ }^{-1}$. Kapurthala showed increase in maximum and minimum 
Table 1: Temporal variability in maize yield in different districts of Punjab from 1971-2017

\begin{tabular}{lllll}
\hline Station & Yield \pm S.D. $\left(\mathrm{kgha}^{-1}\right)$ & $\mathrm{CV}(\%)$ & Rate of change $\left(\mathrm{kg} \mathrm{ha}^{-1}\right.$ year $\left.{ }^{-1}\right)$ & $\mathrm{R}^{2}$ \\
\hline Gurdaspur & $1828 \pm 647.1$ & 35.4 & 36.8 & 0.61 \\
Hoshiarpur & $2352.2 \pm 932.3$ & 39.6 & 62.3 & 0.84 \\
Roopnagar & $2079.9 \pm 862.8$ & 41.5 & 56.8 & 0.81 \\
Amritsar & $2502.8 \pm 1022.4$ & 40.8 & 59.2 & 0.63 \\
Kapurthala & $2762.5 \pm 1274.8$ & 46.1 & 71.4 & 0.59 \\
Jalandhar & $2640.3 \pm 939.1$ & 35.6 & 61.6 & 0.81 \\
Ludhiana & $2873.6 \pm 1286.9$ & 44.8 & 70.8 & 0.57 \\
Patiala & $2364 \pm 1268.9$ & 53.7 & 74.3 & 0.64 \\
\hline
\end{tabular}

Table 2: Temporal variability (1971-2017) climatic parameters in Punjab

\begin{tabular}{|c|c|c|c|c|}
\hline District & Test & Maximum temperature & Minimum temperature & Rainfall \\
\hline \multirow[t]{3}{*}{ Amritsar } & Mean \pm SE & $35.7 \pm 0.1$ & $24.5 \pm 0.1$ & $549.3 \pm 28.2$ \\
\hline & $\mathrm{Z}$ & -0.33 & 1.63 & 0.42 \\
\hline & Q & 0.00 & 0.01 & 0.19 \\
\hline \multirow[t]{3}{*}{ Gurdaspur } & Mean \pm SE & $33.3 \pm 0.2$ & $23.0 \pm 0.2$ & $765.4 \pm 35$ \\
\hline & $\mathrm{Z}$ & 1.28 & $5.52 * * *$ & -0.42 \\
\hline & Q & 0.01 & 0.04 & -0.31 \\
\hline \multirow[t]{3}{*}{ Hoshiarpur } & Mean \pm SE & $34.3 \pm 0.2$ & $23.9 \pm 0.2$ & $709.5 \pm 32.5$ \\
\hline & $\mathrm{Z}$ & $3.32 * * *$ & $5.78 * * *$ & 0.16 \\
\hline & Q & 0.03 & 0.04 & 0.07 \\
\hline \multirow[t]{3}{*}{ Jalandhar } & Mean \pm SE & $34.6 \pm 0.2$ & $24.5 \pm 0.1$ & $760.5 \pm 79.5$ \\
\hline & $\mathrm{Z}$ & -0.24 & $5.59 * * *$ & 0.85 \\
\hline & Q & 0.00 & 0.03 & 0.53 \\
\hline \multirow[t]{3}{*}{ Kapurthala } & Mean \pm SE & $35.2 \pm 0.2$ & $24.6 \pm 0.2$ & $643.4 \pm 32.9$ \\
\hline & $\mathrm{Z}$ & $3.15^{* *}$ & $6.07 * * *$ & -0.03 \\
\hline & Q & 0.03 & 0.04 & 0.00 \\
\hline \multirow[t]{3}{*}{ Ludhiana } & Mean \pm SE & $34.7 \pm 0.1$ & $25.3 \pm 0.1$ & $593.0 \pm 33.4$ \\
\hline & $\mathrm{Z}$ & -0.50 & $6.86^{* * *}$ & 0.15 \\
\hline & Q & 0.00 & 0.05 & 0.08 \\
\hline \multirow[t]{3}{*}{ Patiala } & Mean \pm SE & $33.8 \pm 0.2$ & $24.0 \pm 0.2$ & $616.6 \pm 37$ \\
\hline & Z & $3.25^{* *}$ & $6.02 * * *$ & -0.01 \\
\hline & $\mathrm{Q}$ & 0.03 & 0.05 & -0.02 \\
\hline \multirow[t]{3}{*}{ Roopnagar } & Mean \pm SE & $33.5 \pm 0.3$ & $23.4 \pm 0.2$ & $748.8 \pm 33.9$ \\
\hline & $\mathrm{Z}$ & $3.37 * * *$ & $5.65 * * *$ & $1.79+$ \\
\hline & $\mathrm{Q}$ & 0.03 & 0.04 & 1.04 \\
\hline
\end{tabular}

Z: Mann-Kendall test, Q: Sen's slope estimator **Statistically significant at the $1 \%$ significance level, $* * *$ Statistically significant at the $0.1 \%$ significance level, + Statistically significant at $10 \%$ significance level 
Table 3 : Correlation of maize yield with climate and fertilizer and irrigation variables in different districts of Punjab

\begin{tabular}{llllll}
\hline Districts & $\begin{array}{l}\text { Maximum } \\
\text { temperature }\end{array}$ & $\begin{array}{l}\text { Minimum } \\
\text { temperature }\end{array}$ & Rainfall & Fertilizers & $\begin{array}{l}\text { Gross } \\
\text { irrigated area }\end{array}$ \\
\hline Amritsar & 0.049 & 0.123 & 0.052 & 0.026 & $-0.718^{* *}$ \\
Gurdaspur & 0.147 & $0.563^{* *}$ & -0.172 & $0.699^{* *}$ & $-0.511^{* *}$ \\
Hoshiarpur & $0.67 * *$ & $0.812^{* *}$ & -0.088 & $0.773^{* *}$ & $0.822^{* *}$ \\
Jalandhar & 0.182 & $0.648^{* *}$ & $0.447^{* *}$ & $0.294^{*}$ & $-0.804^{* *}$ \\
Kapurthala & $0.579^{* *}$ & $0.689^{* *}$ & -0.171 & $0.608^{* *}$ & $-0.643^{* *}$ \\
Ludhiana & -0.045 & $0.52^{* *}$ & -0.08 & $0.39^{* *}$ & $-0.466^{* *}$ \\
Patiala & $0.629^{* *}$ & $0.856^{* *}$ & -0.041 & $0.481^{* *}$ & $-0.515^{* *}$ \\
Roopnagar & $0.685^{* *}$ & $0.766^{* *}$ & 0.106 & $0.345^{*}$ & $0.365^{*}$ \\
\hline
\end{tabular}

* Correlation is significant at 5\% significance level (2-tailed)

** Correlation is significant at $1 \%$ significance level (2-tailed)

temperature @ 0.03 and $0.04{ }^{\circ} \mathrm{C}$ year ${ }^{-1}$ respectively. Ludhiana showed significant increase in minimum temperature @ $0.05^{\circ} \mathrm{C}_{\text {year }}{ }^{-1}$. Patiala showed significant increase in maximum and minimum temperature @ 0.03 and $0.05^{\circ} \mathrm{C}$ year ${ }^{-1}$ respectively and Roopnagar showed significant increase in maximum and minimum temperature @ 0.03 and $0.04{ }^{\circ} \mathrm{C}$ year $^{-1}$ respectively (Table2).

Spatial interpretation showed variability showed that maximum temperature at Gurdaspur, Roopnagar and Patiala remained between $33-34^{\circ} \mathrm{C}$, at Hoshiarpur, Jalandhar and Ludhiana, it remained between $34-35^{\circ} \mathrm{C}$ and at Amritsar and Kapurthala it remained between $35-36^{\circ} \mathrm{C}$ (Fig. 1). Minimum temperature at Gurdaspur and Roopnagar remained between 23.0-23. $5^{\circ} \mathrm{C}$, at Hoshiarpur, it remained between 23.5 $24.0^{\circ} \mathrm{C}$, at Patiala, it remained between $24.0-24.5^{\circ} \mathrm{C}$, at Amritsar, Jalandhar and Kapurthala, it remained between 24.5-25. $0^{\circ} \mathrm{C}$ and at Ludhiana minimum temperature remained between $25.0-25.5^{\circ} \mathrm{C}$ (Fig. 1). Similarly, rainfall at Amritsar remained between $500-550 \mathrm{~mm}$, at Ludhiana, it remained between 550-600 mm, at Kapurthala and Patiala, it remained between 600-650 mm, at Hoshiarpur and Roopnagar, it remained between $700-750 \mathrm{~mm}$ and at Gurdaspur and Jalandhar rainfall remained between 750-800 mm (Fig. 1). Acquah and Kyei (2012) showed that average maize yield is positively related to crop area and negatively related to rainfall and temperature. Furthermore, increase in crop area and temperature will enlarge maize yield variability while rainfall increase will decrease the variability in maize yield.

\section{Effect of climate and technology variables on maize yield}

A significantly positive relationship was observed between maize yield and gross irrigated area at Amritsar $(\mathrm{r}=-0.718)$. At Gurdaspur yield was significantly correlated with minimum temperature $(r=0.563)$, fertilizers $(r=0.699)$ and Gross irrigated area $(\mathrm{r}=-0.511)$. At Hoshiarpur, yield was significantly correlated with maximum temperature $(\mathrm{r}=0.67)$, minimum temperature $(\mathrm{r}=0.812)$, fertilizers $(\mathrm{r}=0.773)$ and gross irrigated area $(\mathrm{r}=0.822)$. At Jalandhar, yield was significantly correlated with minimum temperature $(\mathrm{r}=0.648)$, rainfall $(\mathrm{r}=0.447)$, fertilizers $(\mathrm{r}=0.294)$ and gross irrigated area $(\mathrm{r}=-0.804)$. At Kapurthala, yield was significantly correlated with maximum temperature $(\mathrm{r}=0.579)$, minimum temperature $(\mathrm{r}=0.689)$, fertilizers $(\mathrm{r}=0.608)$ and gross irrigated area $(\mathrm{r}=-0.643)$. At Ludhiana, yield was significantly correlated with minimum temperature $(\mathrm{r}=0.52)$, fertilizers $(\mathrm{r}=$ $0.39)$ and gross irrigated area $(\mathrm{r}=-0.466)$. At Patiala, yield was significantly correlated with maximum temperature $(\mathrm{r}=$ 0.629), minimum temperature $(\mathrm{r}=0.856)$, fertilizers $(\mathrm{r}=0.481)$ and gross irrigated area $(\mathrm{r}=-0.515)$. At Roopnagar, yield was significantly correlated with maximum temperature $(\mathrm{r}=$ $0.685)$, minimum temperature $(\mathrm{r}=0.766)$, fertilizers $(\mathrm{r}=0.345)$ and gross irrigated area $(\mathrm{r}=0.365)$ (Table 3$)$. Ogada and Nyangena (2015) also reported that inorganic fertilizers and improved maize varieties significantly improve yields when adopted as a package rather than as individual elements.

\section{Delineation of maize growing regions of Punjab}

The interpolation of different layers of climatic parameters and maize yield divided the maize growing areas into four zones. The first zone covering the districts of Gurdaspur and Roopnagar having maximum temperature range of $33-34^{\circ} \mathrm{C}$, minimum temperature range of $23-24^{\circ} \mathrm{C}$, rainfall range of 600-900 $\mathrm{mm}$ and maize yield of 1000-2000 $\mathrm{kg} \mathrm{ha}{ }^{-1}$. Second zone comprised of Hoshiarpur having maximum temperature range of $34-37^{\circ} \mathrm{C}$, minimum 


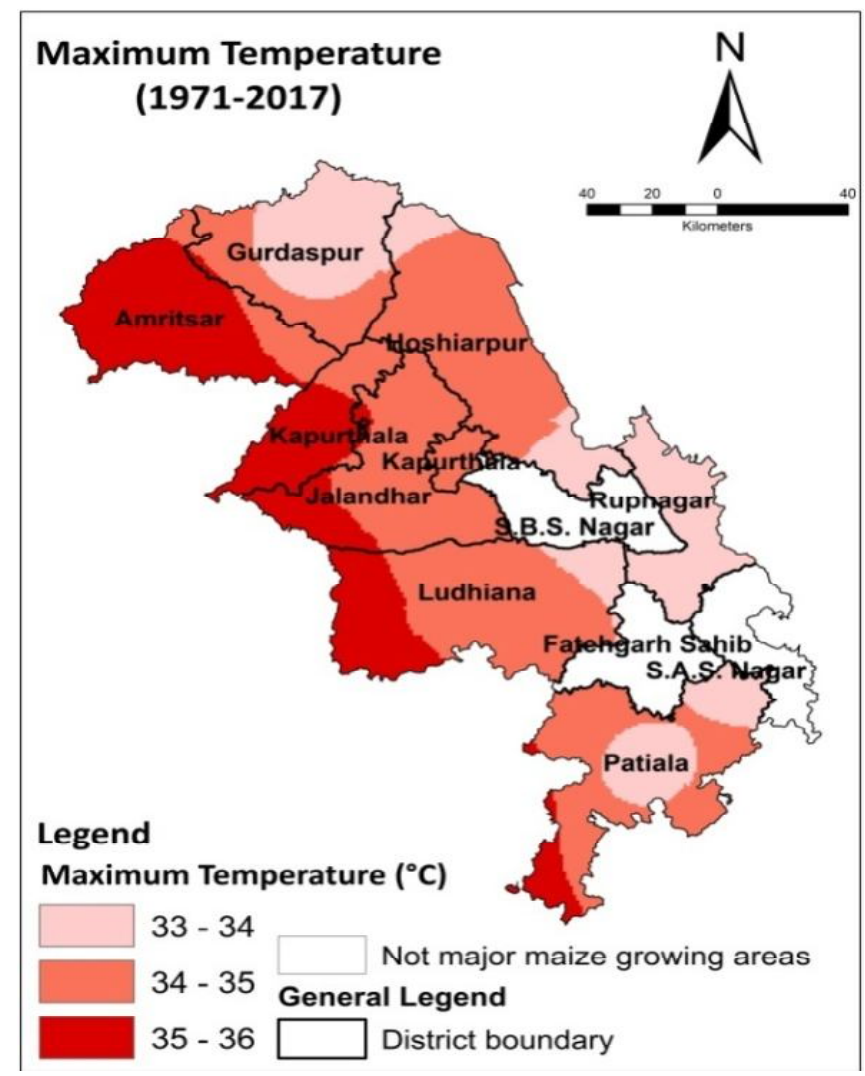

a)

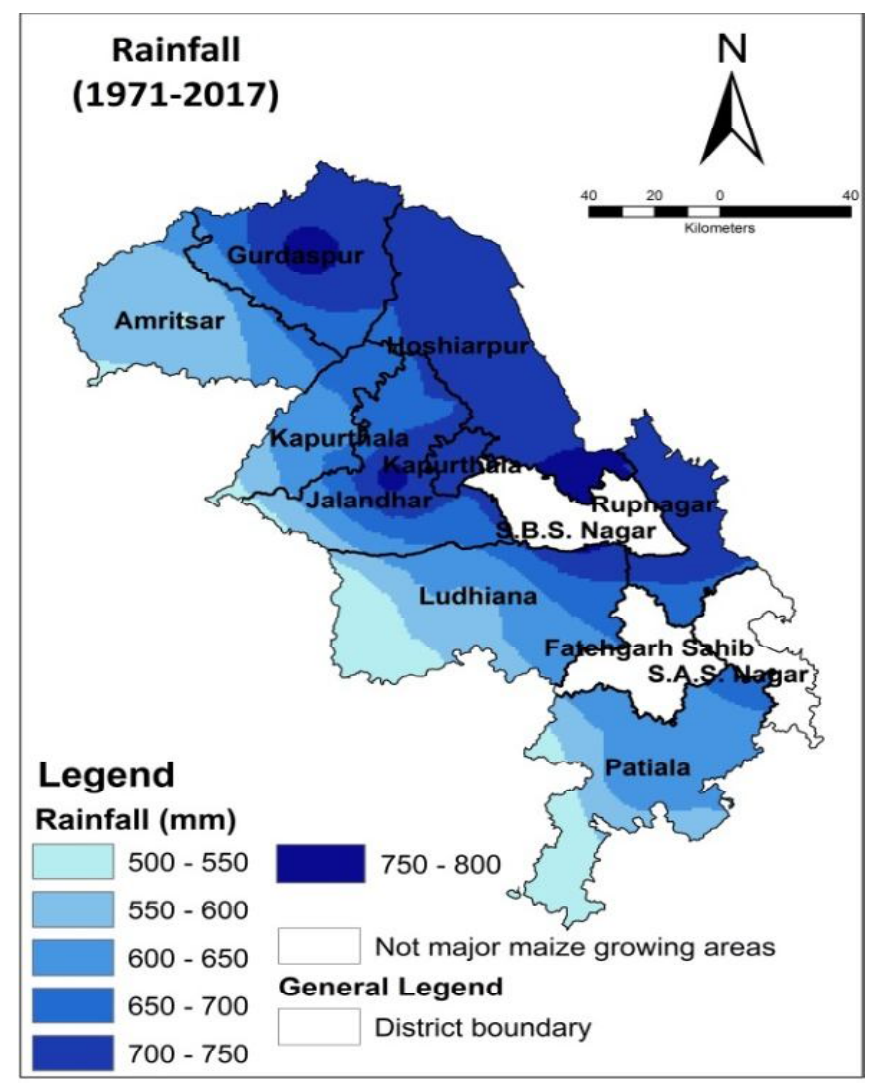

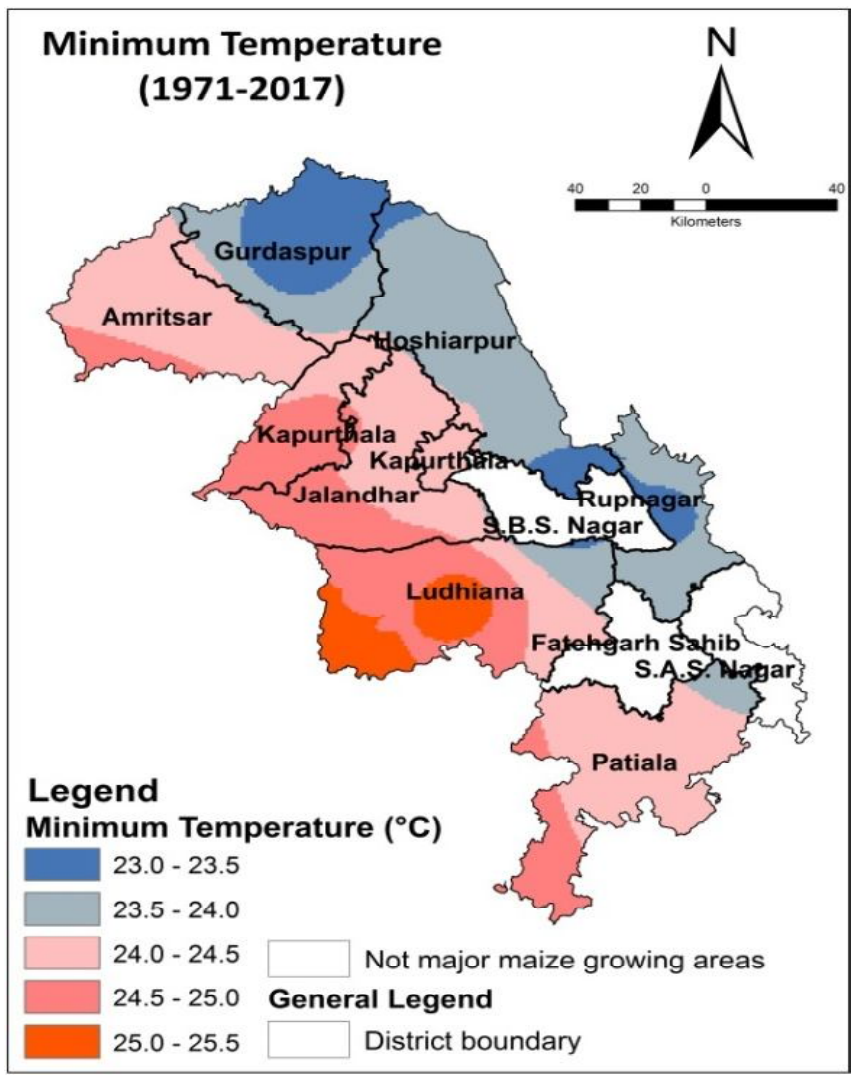

b)

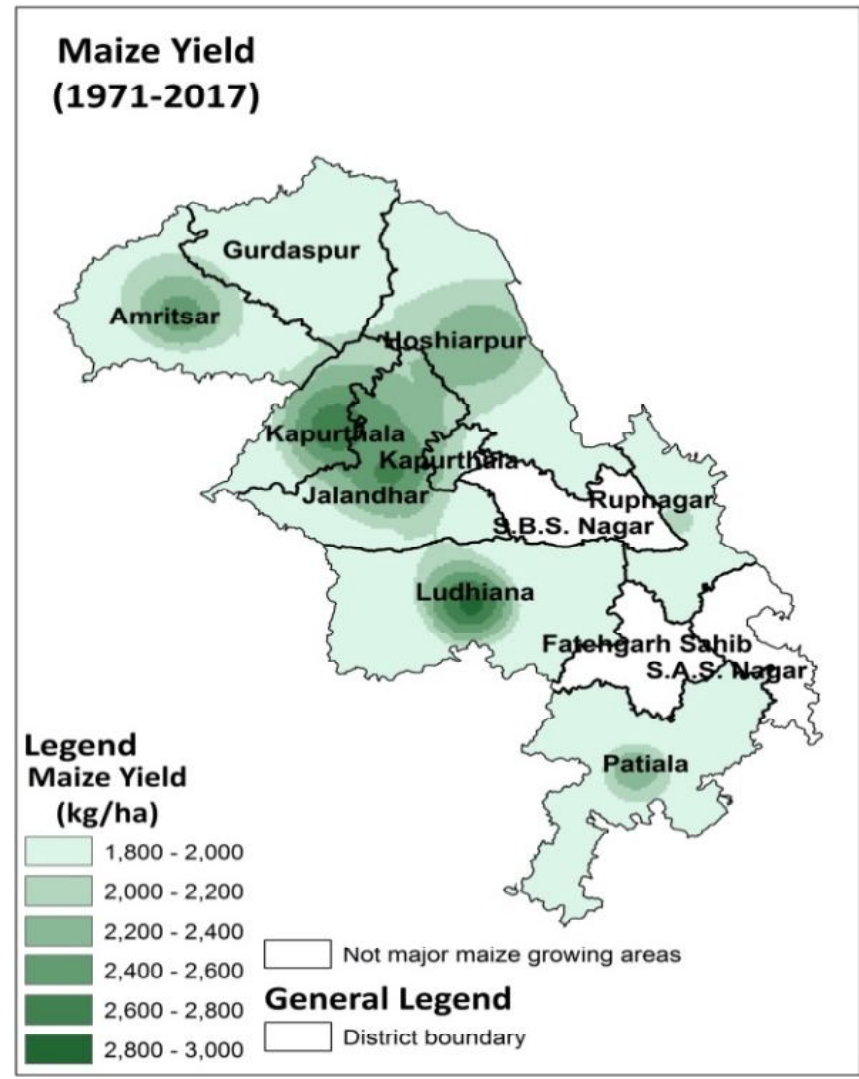

Fig 1 Spatial variability in climatic parameters and its relations with maize yield 


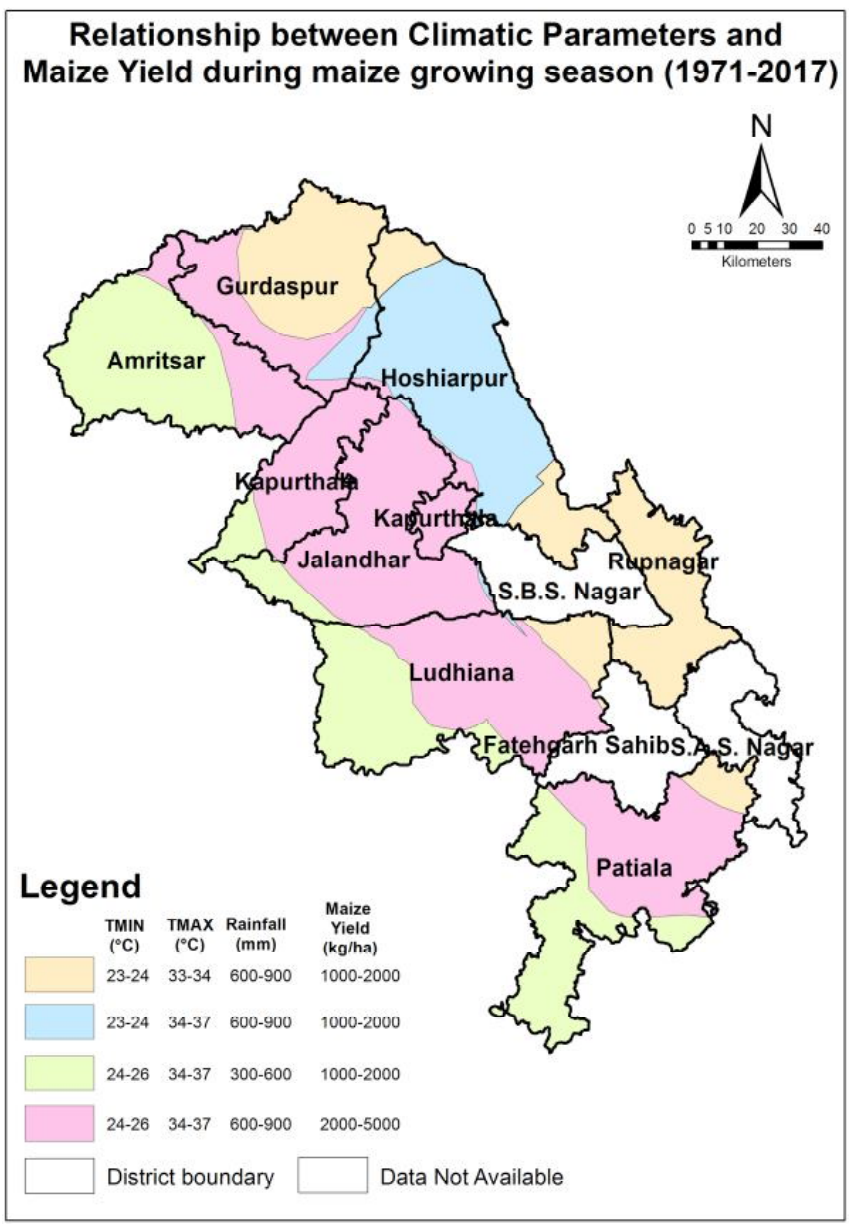

Fig 2 Demarcation maize growing regions of Punjab

temperature range of $23-24^{\circ} \mathrm{C}$, rainfall range of $600-900 \mathrm{~mm}$ and maize yield of $1000-2000 \mathrm{~kg} \mathrm{ha}^{-1}$. Third zone comprises of Amritsar having maximum temperature range of $34-37^{\circ} \mathrm{C}$, minimum temperature range of $24-26^{\circ} \mathrm{C}$, rainfall range of $300-600 \mathrm{~mm}$ and maize yield of $1000-2000 \mathrm{~kg} \mathrm{ha}^{-1}$ and fourth zone comprised the districts of Kapurthala, Jalandhar, Ludhiana and Patiala having maximum temperature range of $34-37^{\circ} \mathrm{C}$, minimum temperature range of $24-26^{\circ} \mathrm{C}$, rainfall range of $600-900 \mathrm{~mm}$ and maize yield of $2000-5000 \mathrm{~kg}$ $\mathrm{ha}^{-1}$ (Fig 2). It has been observed that the effect of the different climate parameters and technology variables (fertilizer and irrigation) are variable in spatio-temporal scale. Lobell and Field (2007) reported 8.3\% decrease in maize yield for $1^{\circ} \mathrm{C}$ rise in temperature without considering the effect of water stress. $\mathrm{Hu}$ (2003) reported the technology and climate parameters impact on maize. Genetic variability and availability of nutrients affect the maize yield potential (Huff and Neill, 1982). Kumar et al. (2018) also suggested that maize research has a crucial role to play in enhancing adaptation and mitigation of climate change while also enhancing food security.

\section{CONCLUSION}

The study concluded that maize yield is significantly affected by climate and technology variables. In view of the changing climatic conditions, there is a dire need to adopt the suitable technological innovations to increase crop yield. Under the changing climatic conditions, geospatial technology can be used quite successfully to evaluate their impacts on crop yield and delineation of crop growing areas using geospatial techniques can be of great help to implement various crop productiontechniques at the zone level.

\section{REFERENCES}

Acquah, H.D. and Kyei, C.K. (2012). The effects of climatic variables and crop area on maize yield and variability in Ghana. Russian J. Agric. Socio-Economic Sci., 10(10): $10-13$.

Anonymous (2019) Package of Practices for Kharif Crops. Pp: 23. Punjab Agricultural University, Ludhiana.

Aronoff S (1991) Geographic information system.A Management Perspective.WLD Publications, Ottawa, ON, Canada.

Hu, Q. and Buyanovsky, G. (2003). Climate effects on corn yield in Missouri. J Appl. Meteorol. Climatol., 42:1626-635.

Huff, F.A. and Neill, J.C. (1982). Effects of natural climatic fluctuations on the temporal and spatialvariation in crop yields. J. Appl. Meteorol., 21: 540-50.

IPCC. (2014). Climate change impacts, adaptation and vulnerability. Contribution of Working Group II to the FifthAssessment Report of the Intergovernmental Panel on Climate Change.Cambridge University Press, Cambridge, United Kingdom and New York, NY, USA. pp: 1150

Johkan, M., Oda, M., Maruo, T. and Shinohara, Y. (2011). Crop production and global warming impacts, case studies on the economy, human health and on urban and natural environments. http://www.intechopen.com.

Kingra, P.K., Setia, R., Singh S., Kaur J., Kaur S., Singh, S. P., Kukal, S.S. and Pateriya, B. (2017). Climatic variability and its characterization over Punjab, India. $J$. Agrometeorol., 19(3): 246-250.

Kumar, K.L.N., Sen, D. and Khanna, V.K. (2018). Effect ofmaize production in a changing climate: Its impact, adaptation and mitigation strategies through breeding. Open Acc. J. Oncol. Med., 2(4): 186-91. 
Liu, Y., Wang, E., Yang, X. and Wang, J. (2010). Contributions of climatic and crop varietal changes to cropproduction in the North China Plain, since 1980s. Glob. Chang. Biol., 16: 2287-299.

Lobell, D.B. and Field, C.B. (2007). Global scale climate-crop yield relationships and the impacts of recentwarming. Environ. Res. Lett., 2:014002. doi:10.1088/1748-9326/ 2/1/014002.

Lobell, D.B., Burke, M.B., Tebaldi, C., Mastrandrea, M.D., Falcon, W.P. and Naylor, R.L. (2008). Prioritizing climate change adaptation and needs for food security in 2030. Science, 319: 607-10.

Lobell, D.B., Roberts, M.J., Schlenker, W., Braun, N., Little, B.B., Rejesus, R.M. and Hammer, G.L. (2014). Greater sensitivity to drought accompanies maize yield increase in the U.S. Midwest. Science, 344: 516-19.

Mo, X., Liu, S., Lin, Z. and Guo, R. (2009). Regional crop yield, water consumption and water use efficiency and their responses to climate change in the North China Plain. Agric. Ecosyst. Environ., 134: 67-78.

Offutt, S.E., Garcia, P. and Pinar, M. (1985). Potential benefits to agriculture of augmenting precipitation. J. Wea. Mod., 17:23-29.
Ogada, M.J. and Nyangena, W. (2015). Impact of Improved Farm Technologies on Yields: The Case of Improved Maize Varieties and Inorganic Fertilizers in Kenya. In International Conference of Agricultural Economists held at Milan, Italy during August 8-14, 2015.

Rathod, S., Singh, K.N., Arya, P., Ray, M., Mukherjee, A., Sinha, K., Kumar, P. and Shekhawat, R.S. (2017). Forecasting maize yield using ARIMA-Genetic Algorithm approach. J Outlook Agr., 46(4): 265-71.

Tao, F. and Zhang, Z. (2011). Impacts of climate change as a function of global mean temperature increase: maize productivity and water use in China. Clim Chang., 105: 409-32.

Xiao, D., Tao, F., Liu, Y., Shi, W., Wang, M., Liu, F., Zhang, S. and Zhu, Z. (2013). Observed changes in winterwheat phenology in the North China Plain for 1981-2009. Int. J. Biometeorol., 57:275-85.

Xiao, D., Qi, Y., Shen, Y., Tao, F., Moiwo, J.P., Liu, J., Wang, R., Zhang, H. and Liu, F. (2015). Impact of warmingclimate and cultivarchange on maize phenologyin the last three decades in North China Plain. Theor. Appl. Climatol., doi: 10.1007/s00704-015-1450-x. 